일반논문-10-15-2-14

$$
\begin{aligned}
& \text { 영상 색온도 변환에 대한 사용자 선호 경향 분석 } \\
& \text { 주 용 수 }{ }^{a)} \text {, 김 상 균ㄹํ }
\end{aligned}
$$

\title{
The Analysis of User Preference Tendency for Color Temperature Conversion of the Image
}

\author{
Yong-Soo Joo ${ }^{\text {a) }}$ and Sang-Kyun $\mathrm{Kim}^{\text {a) }}{ }^{\ddagger}$ \\ 요 약
}

최근 LCD, PDP, OLED와 같은 평판 디스플레이들의 대중적인 인기로 인해 디스플레이 화질 및 색 개선에 대한 연구가 활발히 이 루어지고 있다. 최적의 디스플레이 색을 제공하기 위한 연구들 중 하나로, 사용자 선호도에 기반한 영상 색온도 자동 변환 연구가 있 다. 본 논문에서는 기존의 사용자 선호도 기반 색온도 변환 방법에 대한 문제점을 정의하고, MPEG-7 색온도 서술자에서 제시된 색온 도 구간에 따른 사용자 선호도 경향을 검증한다. 분석된 사용자 선호도에 근거하여 최적 색온도 변환 커브를 제시한다. 일원분산분석 (ANOVA)을 통해 분석한 결과, 색온도 구간에 대한 사용자 선호도 경향은 기존의 연구 결과와 유사한 결과를 보였고, 반복 색온도 변 환 실험의 결과는 통계적으로 유의하지 않았다.

\begin{abstract}
Recently, researches to improve a quality and a color of a display are being actively studied because of the prosperous growth of the flat panel displays such as LCD, PDP and OLED. Automatically adjusting color temperatures based on user preferences is the one of the researches to provide the optimum display color. In this paper, along with defining the problems of prior methods, the user preferences against the priori defined ranges proposed by the MPEG-7 color temperature descriptor are inspected. Based on the analysis of user preferences, an optimal color temperature conversion curve is proposed. As a result of an analysis by ANOVA, tendencies of the user preferences against each range are proven to be similar to the prior research results. The repetition of the color temperature conversion against an image is not statistically significant.
\end{abstract}

Keyword : color temperature, color temperature conversion, user preference tendency, MPEG-7 color temperature descriptor

\section{I. 서 론}

최근 $\mathrm{LCD}, \mathrm{PDP}, \mathrm{OLED}$ 와 같은 평판 디스플레이들의 대

a) 명지대학교 컴퓨터공학과

Department of Computer Engineering, Myongji University

₹ 교신저자 : 김상균 (goldmunt@gmail.com)

※ 이 논문은 2008 년 정부(교육과학기술부)의 재원으로 한국학술진흥재단

의 지원을 받아 수행된 연구임(KRF-2008-331-D00561)

· 접수일(2010년1월12일),수정일(2010년3월9일),게재확정일(2010년3월9일)
중적인 인기로 인해, 디스플레이 화질 및 색을 개선하기 위 한 연구들이 활발히 이루어지고 있다. 이 연구들은 크게 두 가지로, 첫 번째는 디스플레이 장치의 특성을 고려한 화질 및 색 개선에 관련된 연구들 ${ }^{[1-3]}$ 이 있고, 두 번째는 영상 자 체의 화질 및 색 개선에 관련된 연구들[-6-6]이 있다. 이에 더 불어 사용자의 선호 경향을 고려한 화질 및 색 개선에 관련 된 연구들 $[7-9]$ 도 있다. 이 중에서 사용자의 선호 경향을 바 탕으로 영상의 색온도를 변환하는 방법 ${ }^{[9]}$ 은, 디스플레이 장 
치의 특성에 영향을 적게 받고, 사용자의 취향에 따라 디스 플레이 화면의 색감을 개선할 수 있으며, 다양한 디스플레 이 장치에 적용이 가능한 방법이다.

여기서 색온도(color temperature)란 광원으로부터 방사 하는 빛의 색을 온도로 표시한 것이다. 흑체는 온도에 따라 방사하는 빛의 색이 변화하는 특성이 있어, 이 흑체의 온도 를 색온도로 정의하였으며 절대온도 켈빈 $(\mathrm{K})$ 단위로 나타 낸다. 흑체의 궤적(black body locus)은 흑체의 온도가 상승 함에 따라 방사하는 빛의 색이 적색-백색-청색 순으로 변해 가면서 만들어지는 궤적으로서, CIE 1931 색공간의 xy 색 도분포표 상에 표시된다. 상관색온도(correlated color temperature)란 일반적인 광원들이 흑체의 궤적으로부터 다소 벗어난 색좌표값을 가지고 있어, 이를 근사시킨 색온도로 표시한 것이다 ${ }^{[10]}$. 디스플레이 장치에서는 이 상관색온도를 색온도의 의미로 사용하며, 디스플레이 장치의 광원색이나 백색점(white point)으로 표현된다.

일반적으로 영상을 획득하는 과정이나, 출력하는 과정에 서 색온도 변환이 필요하다. 디지털 카메라와 같은 디지털 영상 입력 장치로부터 영상을 획득하는 과정에서 광원의 색온도의 영향으로 인해 획득되는 영상의 색감이 실제로 보는 것과 다르게 느껴지게 된다. 예를 들어, 동일한 물체를 대상으로 정오의 태양 빛 아래에서 촬영한 영상과 형광등 아래에서 촬영한 영상을 비교하면 물체의 색감이 다르게 느껴지게 된다. 이는 촬영 당시의 광원에 따라 획득되는 영 상의 색온도가 달라졌기 때문이다. 이를 해결하기 위해, 색 온도 보정을 이용한 영상 개선 방법이 연구되었다 ${ }^{[1]}$. 반대 로 디스플레이 장치와 같은 디지털 영상 출력 장치로 영상 을 출력하는 과정에서는, 디스플레이 장치의 광원색에 따 라 출력되는 영상의 색감이 달라진다. 이를 해결하기 위해, 대부분의 디스플레이 장치는 사용자가 색온도를 조절할 수 있는 기능을 제공하고 있다.

디스플레이 장치에서의 색온도 조절은 사용자의 선호에 따라 $\mathrm{D} 50(5003 \mathrm{~K}), \mathrm{D} 65(6504 \mathrm{~K}), 9300 \mathrm{~K}$ 중 하나의 색온도 를 선택할 수 있도록 되어 있다. 이는 영상을 따뜻한 느낌의 색(붉은) 쪽으로 변환하거나 시원한 느낌의 색(푸른) 쪽으 로 변환하는 것으로, 어떤 광원으로부터 방사하는 빛의 색 이 색온도가 낮을 때는 붉은색을 띄지만 색온도가 높을 때
는 푸른색을 띄게 되는 색온도의 특징과 관련이 있다. 그러 나 이러한 디스플레이 장치의 색온도 변환은 화면 자체의 색감을 사용자가 정하는 일정한 색온도(예: $6504 \mathrm{~K})$ 에 고정 시켜 버리는 단점이 있다. 이를 극복하기 위해서 사용자의 색온도 선호 경향을 디스플레이 되는 동영상에 가변적으로 반영한 영상 색온도 변환 방법이 연구되었다 ${ }^{[9]}$.

그러나 기존의 연구 ${ }^{[9]}$ 에서는 제안된 방법에 대한 성능 평 가 실험 결과를 제시하지 못하였다. 또한 사용자의 선호 경 향에 따라 색온도가 변환된 영상을 보여주었을 때, 사용자 가 또 다시 영상의 색온도를 변환하고 싶어 한다면, 이를 반영한 새로운 방법이 제시되어야 한다. 예를 들어, 사용자 의 선호 경향에 따라 색온도가 높은(푸른) 쪽으로 변환시킨 영상을 사용자에게 보여주었을 때, 만족하지 못하고 색온 도를 더 높은(푸른) 쪽으로 변환시키기를 원할 수 있고, 반 대로 더 낮은(붉은) 쪽으로 변환시키기를 원할 수도 있다. 따라서 사용자의 선호 경향에 따라 색온도가 변환된 결과 영상에 대해, 색온도를 재 변환하고자 하는 경향의 존재 가 능성을 조사하고 검증해야 한다.

이에 따라 본 연구에서는 먼저, 기존 연구 ${ }^{[9]}$ 에서 제안된 방법에 대한 성능 평가 실험을 수행하고 그 결과를 분석하 여, 개선되어야 할 점을 제시한다. 그 다음, 기존 연구 결과 의 바탕이 되는 영상 색온도 변환에 대한 사용자의 선호 경향을 검증하고, 한 번 이상 변환된 영상 색온도의 재 변 환 가능성에 대한 조사와 검증을 위해, 색온도 변환에 대한 사용자 선호 경향 조사 실험을 수행하였다. 실험 결과는 객관적이고 정량화된 분석을 위해 일원분산분석(ANOVA, ANalysis Of VAriance) 평가를 실시하였다. 마지막으로 일 원분산분석 결과와 함께 색온도 변화량에 대한 분석 결과 를 바탕으로, 최적의 색온도 변환 곡선을 제시한다.

\section{II. 기존 색온도 변환 방법 및 성능 평가}

\section{1. 기존의 사용자 선호 기반 영상 색온도 변환 방법}

기존 연구 ${ }^{[0]}$ 에서는 색온도 변환에 대한 사용자의 선호 경 향을 조사하기 위해, MPEG-7 색온도 서술자에서 제시된 
4가지의 색온도 카테고리 ${ }^{[12-14]}$ 로 나누었다. MPEG-7 색온 도 서술자는 영상으로부터 색온도를 추출하거나 변환하는 데 필요한 정보들을 표준화된 방법으로 서술하기 위해 제 안된 방법으로서 현재 MPEG 표준으로 제정되어 있다. MPEG-7 색온도 서술자에서 제시된 4가지의 색온도 카 테고리는 색온도 전체 구간 $(1667 \mathrm{~K} 25000 \mathrm{~K})$ 을 인간의 지 각을 기반으로 분류한 것으로, 각각 $\operatorname{Hot}(1667 \mathrm{~K} 2250 \mathrm{~K})$, Warm(2251K 4170K), Moderate(4171K 8060K), Cool (8061K 25000K) 카테고리로 정의된다. 이러한 분류 기준 에 따라, 영상에서 추출된 색온도를 이용하여 해당 영상이 속하는 색온도 카테고리를 결정하게 된다.

그림 1 은 기존 연구 ${ }^{[9]}$ 에서 조사했던, 색온도 변환에 대한 사용자의 선호 경향을 보여주는 그림이다. 먼저, 영상의 색 온도 변환에 대한 선호 경향을 따뜻한 쪽(warmer)과 변하 지 않는 쪽(original), 시원한 쪽(cooler)으로 구분하였다. 그 리고 각각의 색온도 변환에 대한 선호 경향에서, 각 영상이 속하는 카테고리 내의 사용자 선호도를 표시하였다.

그림 1의 (a)를 보면, Hot과 Warm 카테고리에 속하는 영
상들에 대해서 따뜻한 쪽으로의 색온도 변환을 선호하는 것을 알 수 있다. 그림 1 의 (c)에서는 Moderate와 Cool 카테 고리에 속하는 영상들에 대해서 시원한 쪽으로의 색온도 변환을 선호하는 것을 알 수 있다. 그러나 색온도를 변하지 않는 쪽을 선호하는 경향은 그림 1 의 (b)에서 보듯이, 다른 선호 경향들에 비해 선호도 작다는 것을 알 수 있다. 즉, 대부분의 사용자들은 원 영상 보다, 따뜻한 느낌의 영상에 대해서는 좀 더 따뜻하게, 시원한 느낌의 영상에 대해서는 좀 더 시원하게, 색온도가 변환된 영상을 더 선호하는 것을 알 수 있다.

그림 2는 영상 및 동영상 콘텐츠 내의 각 영상들에 대한 자동 색온도 변환의 흐름을 보여준다. 영상의 색온도를 변 환하는 과정에는 두 가지의 중요한 과정이 있다. 첫 번째 과정은 상기 색온도 선호 경향을 반영하는 색온도 맵핑 과 정이다. 즉, 입력 영상의 색온도로부터 사용자의 색온도 선 호 경향이 반영된 목표 색온도를 결정하는 과정이다. 두 번 째 과정은 첫 번째 과정을 통해 얻은, 목표 색온도로 변환된 영상을 얻는 과정이다. 즉, 사용자의 색온도 선호 경향이

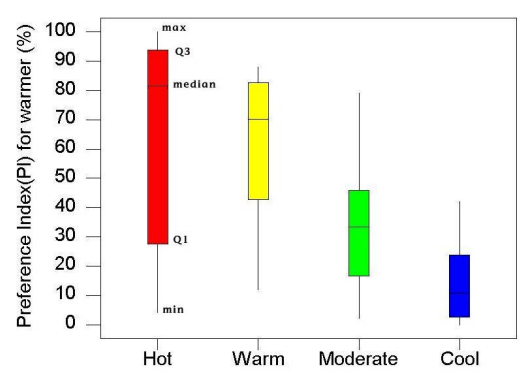

(a)

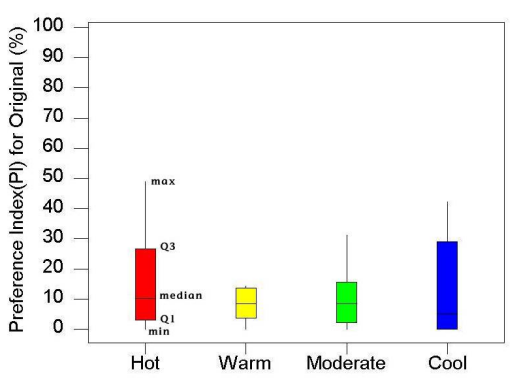

(b)

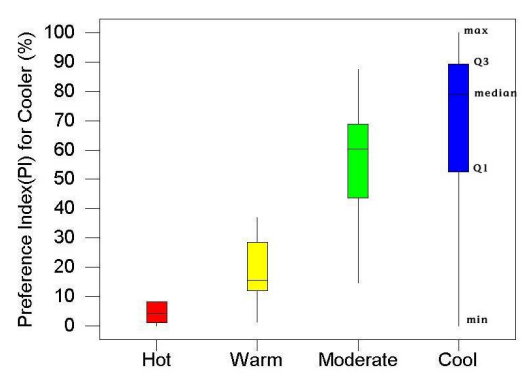

(c)

그림 1. 색온도 변환에 대한 사용자의 선호 경향이

Fig. 1. User preference tendency plots on the color temperature conversion ${ }^{[9]}$

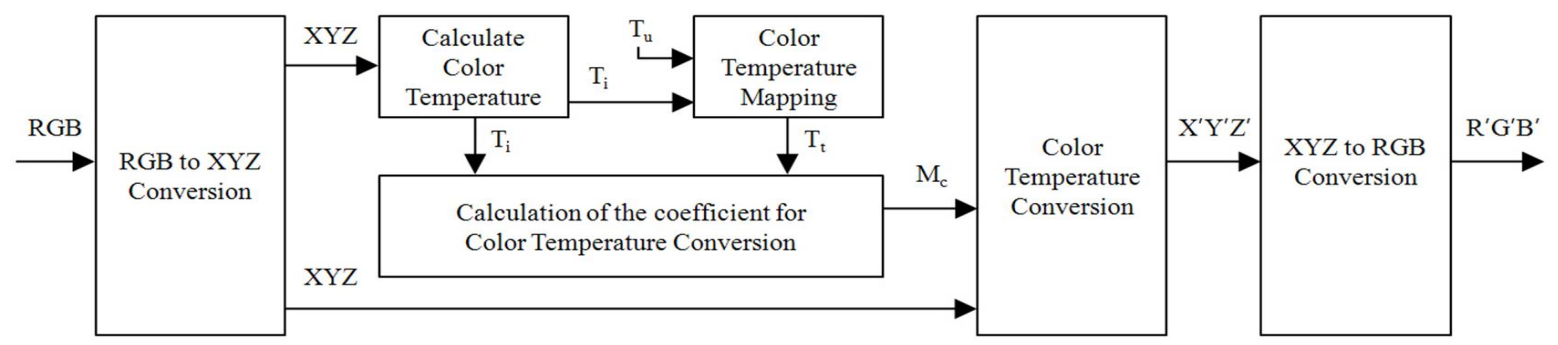

그림 2. 영상 및 동영상 내의 각 영상의 색온도를 변환하는 흐름도 ${ }^{[9]}$

Fig. 2. A flow diagram converting color temperatures of an image in video ${ }^{[9]}$ 
반영된 최종 영상을 구하는 과정이다. 이 중에서 목표 색온 도를 결정하는 과정이 사용자의 선호 경향을 반영한 색온 도 변환에 있어 핵심이 되는 과정이다.

기존 연구 ${ }^{[9]}$ 에서 제안된 목표 색온도 $\left(\mathrm{T}_{\mathrm{t}}\right)$ 를 결정하는 방 법은 다음과 같다. 먼저, 테스트용 기준 영상을 보여준 뒤 사용자가 테스트용 기준 영상의 색온도 $\left(\mathrm{T}_{\mathrm{r}}\right)$ 를 변환시키도 록 유도하고, 사용자가 최종적으로 변환시킨 색온도를 그 사용자의 선호 색온도 $\left(\mathrm{T}_{\mathrm{u}}\right)$ 로 결정한다. 그 다음 사용자의 선호 색온도 $\left(T_{u}\right)$ 가 테스트용 기준 영상의 색온도 $\left(T_{r}\right)$ 보다 높은지 $\left(\mathrm{T}_{\mathrm{u}}>\mathrm{T}_{\mathrm{r}}\right)$ 혹은 낮은지 $\left(\mathrm{T}_{\mathrm{u}}<\mathrm{T}_{\mathrm{r}}\right)$ 를 판별한다. 판별된 결과에 따라 해당 사용자의 선호 경향을 반영한 가중치 함 수를 선택하고, 목표 색온도 결정에 사용될 가중치 $(\Theta)$ 를 계 산한다. 이렇게 구해진 가중치 $(\Theta)$ 와 입력 영상의 색온도 $\left(\mathrm{T}_{\mathrm{i}}\right)$ 를 곱하면, 사용자의 선호 경향이 반영된 목표 색온도 $\left(\mathrm{T}_{\mathrm{t}}\right)$ 를 구할 수 있다.

\section{2. 기존 색온도 변환 방법의 성능 평가 실험 및 분석}

\section{1. 실험 환경}

기존 연구 ${ }^{[9]}$ 에서 제안된 색온도 변환 방법의 성능 평가 실험 환경에 대해 표 1 과 같이 정리하였다. 실험대상자는 대학교에 재학 중인 남, 여 17명을 대상으로 하였으며, 색상 인지에 문제가 없는 21 25세의 사람들로 구성되었다. 실험 장비는 24인치 BTC Zeus $7000 \mathrm{LCD}$ 모니터를 사용하였으 며, 실험실은 색인지에 대한 외부 영향을 최소화 할 수 있는 암실 환경으로 조성하였다.

표 1. 기존 방법 ${ }^{[y]}$ 에 대한 성능 평가 실험 환경

Table 1. The experiment condition of the priori proposed method by [9]

\begin{tabular}{|c|c|}
\hline 피 험 자 & $\begin{array}{c}\text { 대 } \\
\text { 상: 대학교 재학중인 남녀 17명 (남:13명, 여:4명) } \\
\text { 낙으이사항: 색상 인지 문제 없음 (색맹, 색약 아님) }\end{array}$ \\
\hline 실험장비 & BTC Zeus 7000 LCD Monitor (24인치) \\
\hline 실험환경 & 암실 (외부로부터 모든 빛 차단) \\
\hline 실험영상 & $\begin{array}{c}\text { Corel 1.3M Photo Gallery에서 160장 선정 } \\
\text { (1818K 12500K 색온도 구간 내의 영상들) }\end{array}$ \\
\hline
\end{tabular}

실험 영상들은 Corel 1.3M Photo Gallery에서 1818K $12500 \mathrm{~K}$ 구간의 색온도를 가진 영상들로 총 160 장을 선정 하였다. 이를 위해 우선 역색온도(reciprocal color temperature)를 기준으로 550 80 사이의 구간(색온도 구간: $1818 \mathrm{~K} \sim 12500 \mathrm{~K})$ 을 20 개의 구간으로 나누었다. 20 개의 구 간 중에서 13 16구간(3731K $5747 \mathrm{~K})$ 은 기존 연구의 색온 도 선호 조사 실험에서 특별한 선호 경향을 보이지 않았던 구간이었기 때문에, 이 구간을 제외한 나머지 구간에서 각 각 10 장씩 영상을 선정하였다. 선정된 영상들은 산, 바다, 정원, 인테리어, 주방, 침실, 풍경등과 같은 자연스러운 영 상들로 구성되어 있다.

\section{2. 실험 진행}

실험대상자들은 그림 3과 같은 성능 평가 실험용 $\mathrm{GUI}$ 를 통해, 원 영상과 색온도 변환 방법이 적용된 영상을 비교하 여 제안된 방법의 성능을 평가하였다. 그림 3의 (a)는 사용 자의 선호 색온도 조사를 위한 실험용 GUI이다. 이를 위해 테스트용 기준 영상을 보여주고 사용자가 색온도를 변환 시키도록 유도하였다. 테스트용 기준 영상은 약 $5000 \mathrm{~K}$ $6500 \mathrm{~K}$ 사이의 색온도에 속하는 영상들 중 배경이나 전체 색감이 백색을 많이 포함하고 있는 영상을 선정하도록 하 였다. 이는 기존 연구 ${ }^{[9]}$ 에서 조사했던, 색온도 변환에 대한 사용자의 선호 경향에서 알 수 있듯이, 보여주는 영상의 느 낌 따라 사용자의 선호 경향이 따라갈 수 있기 때문에, 이러 한 문제점이 최소화될 수 있도록 테스트용 기준 영상을 선 정하였다. 그림 3 의 (b)는 성능 평가를 위한 실험용 GUI로 서, 왼쪽의 영상이 원 영상이며 오른쪽 영상이 기존 연구 ${ }^{[9]}$ 에서 제안된 방법으로 색온도가 변환된 영상이다. 즉, 오른 쪽 영상은 (a)를 통해 조사된 사용자의 선호 색온도와 테스 트용 기준영상의 색온도를 이용하여, 입력 영상의 색온도 가 사용자의 선호에 따라 목표 색온도로 변환된 영상을 보 여준다. 실험대상자들은 두 영상 중 본인이 더 선호하는 영 상에 1점부터 5점 사이의 점수를 선택할 수 있다. 만약 실 험대상자가 0 점을 선택하였다면, 원 영상과 변환된 영상 사 이에 별 차이가 없다고 느끼는 것을 의미한다. 


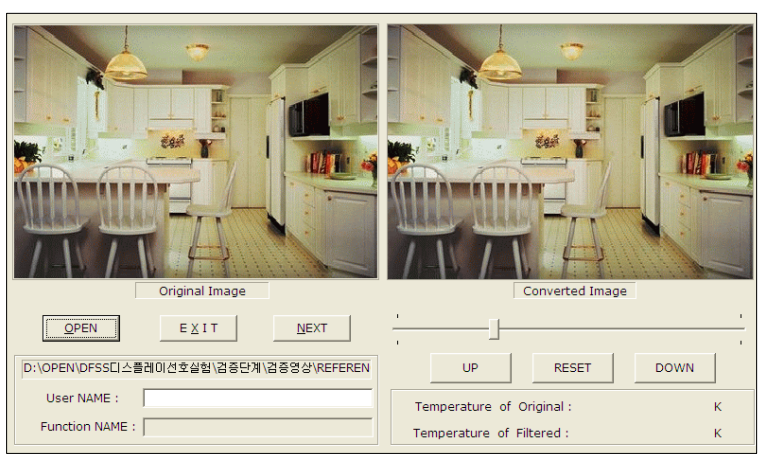

(a)

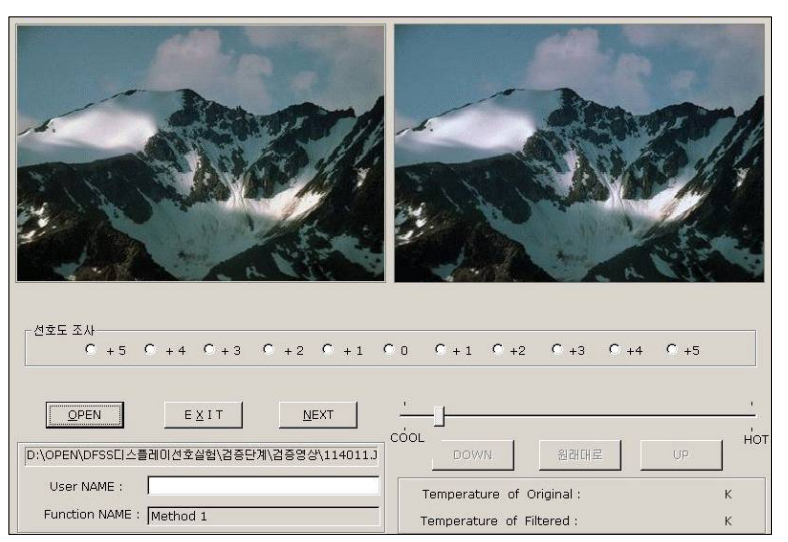

(b)

그림 3. 성능 평가 실험용 GUI

Fig. 3. The GUI of the performance evaluation experiment

\section{3. 실험 결과 및 분석}

성능 평가 실험 결과는 다음과 같은 과정을 통해 정리하 였다.

- 만약 실험대상자가 원 영상을 더 선호하였다면, 선택된 점수를 음수로 변환하였다.

- 점수를 계산하는 방법은 다음과 같다.

: 선호도 $=\sum$ 점수 $*$ 선택 수

: 평균 $=$ 선호도 / 총 선택 수

- 검증 결과: 만약 선호도의 평균이 0 보다 크다면 기존 연구 ${ }^{[9]}$ 에서 제안된 색온도 변환 방법에 의해 변환된 영 상을 더 선호하는 것이고, 그 반대라면 원 영상을 더 선호하는 것이다.

표 2는 상기에 서술한 정리 방법에 의해 성능 평가 실험 결과를 정리한 표이다. 선호도의 전체 평균은 0.66 으로 원

표 2. 성능 평가 실험 결과

Table 2. Performance results of the priori proposed method by [9]

\begin{tabular}{|c|c|c|c|c|c|c|c|c|c|c|c|c|c|}
\hline score & -5 & -4 & -3 & -2 & -1 & 0 & 1 & 2 & 3 & 4 & 5 & $\begin{array}{c}\text { preference } \\
\text { degree }\end{array}$ & average \\
\hline range1 & 0 & 0 & 0 & 5 & 6 & 106 & 40 & 12 & 1 & 0 & 0 & 51 & 0.30 \\
\hline range2 & 0 & 0 & 3 & 4 & 13 & 90 & 39 & 17 & 2 & 0 & 0 & 49 & 0.29 \\
\hline range3 & 0 & 0 & 0 & 2 & 8 & 102 & 41 & 13 & 4 & 0 & 0 & 67 & 0.39 \\
\hline range4 & 0 & 0 & 2 & 3 & 12 & 87 & 49 & 12 & 4 & 1 & 0 & 65 & 0.38 \\
\hline range5 & 0 & 1 & 5 & 7 & 20 & 69 & 40 & 16 & 11 & 1 & 0 & 56 & 0.33 \\
\hline range6 & 0 & 0 & 2 & 2 & 21 & 64 & 42 & 29 & 9 & 1 & 0 & 100 & 0.59 \\
\hline range7 & 0 & 0 & 1 & 1 & 20 & 59 & 52 & 25 & 10 & 2 & 0 & 115 & 0.68 \\
\hline range8 & 0 & 0 & 5 & 7 & 21 & 54 & 47 & 28 & 6 & 2 & 0 & 79 & 0.46 \\
\hline range9 & 0 & 1 & 5 & 15 & 23 & 48 & 46 & 21 & 11 & 0 & 0 & 49 & 0.29 \\
\hline range10 & 0 & 0 & 4 & 6 & 24 & 50 & 50 & 23 & 9 & 4 & 0 & 91 & 0.54 \\
\hline range11 & 0 & 0 & 5 & 3 & 11 & 47 & 64 & 23 & 14 & 1 & 2 & 134 & 0.79 \\
\hline range12 & 0 & 0 & 3 & 2 & 15 & 86 & 42 & 16 & 6 & 0 & 0 & 64 & 0.38 \\
\hline range17 & 2 & 1 & 4 & 5 & 18 & 32 & 40 & 36 & 23 & 8 & 1 & 164 & 0.96 \\
\hline range18 & 1 & 1 & 3 & 1 & 15 & 16 & 49 & 33 & 35 & 14 & 2 & 251 & 1.48 \\
\hline range19 & 0 & 0 & 4 & 3 & 7 & 36 & 50 & 26 & 24 & 16 & 4 & 233 & 1.37 \\
\hline range20 & 0 & 0 & 0 & 5 & 12 & 32 & 53 & 24 & 23 & 15 & 6 & 238 & 1.40 \\
\hline total & 3 & 4 & 46 & 71 & 246 & 980 & 744 & 354 & 192 & 65 & 15 & 1806 & 0.66 \\
\hline
\end{tabular}




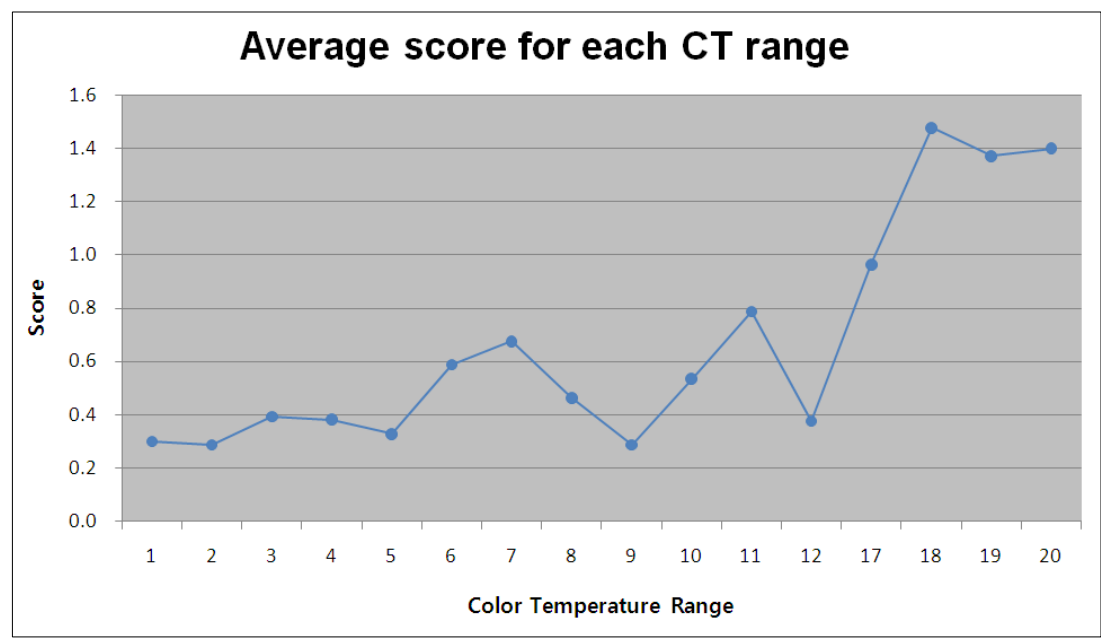

그림 4. 각 색온도 구간 별 평균 점수 분포

Fig. 4. Average score distributions of each color temperature range

영상보다 기존 연구 ${ }^{[9]}$ 에서 제안된 색온도 변환 방법에 의해 변환된 영상을 더 선호하고 있음을 알 수 있다. 원 영상이 더 좋다고(-1점 -5점) 선택한 비율은 약 $14 \%$ 정도이며, 반면 변환된 영상이 더 좋다고(1점 5점) 선택한 비율은 약 $50 \%$ 정도이다.

그림 4는 성능 평가 실험 결과를 각 색온도 구간 별 평균 점수들의 분포도 나타낸 그림이다. 이 분포도를 보면 시원 한 느낌의 색온도 구간(range 17 20: 5747K 12500K)이 다 른 색온도 구간(range 1 12: 1818K 3731K)에 비해 평균 0.85점 높은 것을 알 수 있다. 이는 시원한 느낌의 색온도 구간 안에 있는 영상의 색온도가 변환된 결과를 사용자가 더 많이 선호하고 있다는 것을 말해준다.

실험 결과, 사용자는 대체적으로 원 영상보다 기존 연구 ${ }^{[9]}$ 에서 제안된 색온도 변환 방법에 의해 변환된 영상에 대 해 만족하였으며 특히, 시원한 느낌의 영상을 더 시원하게 변환했을 때 더 만족하는 것을 알 수 있었다. 그러나 대부분 의 사용자들이 따뜻한 느낌의 영상은 더 따뜻하게, 시원한 느낌의 영상은 더 시원하게 변환된 영상을 더 선호하는 경 향을 보였었다는 점을 감안하면 기존 방법보다 더 향상된 색온도 변환 방법이 제공되어야 한다. 또한, 색온도 변환에 대한 사용자의 선호에 따라 변환된 결과 영상에 대해, 사용 자가 색온도를 재 변환하고자 하는 경향이 있다면 이러한
경향이 반영된 색온도 변환 방법이 제공되어야 한다. 예를 들어, 사용자의 선호 경향에 따라 색온도가 높은(푸른, 시원 한 느낌) 쪽으로 변환시킨 영상을 사용자에게 보여주었을 때, 만족하지 못하고 색온도를 더 높은(푸른, 시원한 느낌) 쪽으로 변환시키기를 원할 수 있고, 반대로 더 낮은(붉은, 따뜻한 느낌) 쪽으로 변환시키기를 원할 수도 있다. 따라서 다음 장에서 색온도 변환에 대한 사용자의 선호 경향을 조 사하고, 그 결과를 분석한다.

\section{III. 색온도 변환에 대한 사용자 선호 경향 조사 실험}

\section{1. 실험 환경}

색온도 변환에 대한 사용자 선호 경향 조사 실험 환경에 대해 표 3과 같이 정리하였다. 실험대상자는 대학교에 재학 중인 남, 여 17명을 대상으로 하였으며, 색상인지에 문제가 없고, 기존 색온도 변환 방법 ${ }^{[9]}$ 의 성능 평가 실험에 참여하 지 않았던 22 27세의 사람들로 구성되었다. 실험 장비는 24인치 BTC Zeus 7000 LCD 모니터를 사용하였으며, 실험 실은 색인지에 대한 외부 영향을 최소화 할 수 있는 암실 
환경으로 조성하였다.

표 3. 색온도 변환에 대한 사용자 선호 경향 조사 실험 환경 Table 3. The experiment conditions of the investigation of user preference tendency for color temperature conversion

\begin{tabular}{|c|c|}
\hline 피 험 자 & $\begin{array}{c}\text { 대 상: 대학교 재학중인 남녀 17명 (남:14명, 여:3명) } \\
\text { 나 이: 22 27세 } \\
\text { 특이사항: 색상 인지 문제 없음 (색맹, 색약 아님) }\end{array}$ \\
\hline 실험장비 & BTC Zeus 7000 LCD Monitor (24인치) \\
\hline 실험환경 & 암실 (외부로부터 모든 빛 차단) \\
\hline 실험영상 & $\begin{array}{l}\text { Corel 1.3M Photo Gallery에서 200장 선정 } \\
\text { (1818K 12500K 색온도 구간 내의 영상들) }\end{array}$ \\
\hline
\end{tabular}

실험 영상들은 Corel 1.3M Photo Gallery에서 역색온도 를 기준으로 550 80 사이의 구간(색온도 구간: $1818 \mathrm{~K}$ $12500 \mathrm{~K})$ 을 역색온도 10 간격씩 47 개의 구간으로 나누었다. 그리고 영상들이 골고루 분포될 수 있도록 나열한 뒤, 산, 바다, 정원, 인테리어, 주방, 침실, 풍경등과 같은 자연스러 운 영상들로 총 200 장을 선정하였다.

\section{2. 실험 진행}

실험대상자들은 그림 5 와 같은 실험용 $\mathrm{GUI}$ 를 통해, 각 색온도 구간 별로 고르게 선택된 실험 영상을 보게 되고, 실험 영상의 색온도를 준비된 UI 버튼이나 슬라이드 바를 통해 본인의 기호에 따라 따뜻한(낮은) 쪽이나 시원한(높 은) 쪽으로 변화시킬 수 있다. 그림 6은 준비된 실험용 $\mathrm{GUI}$ 를 통해 색온도가 변환된 영상의 예를 보여준다. 그림 6 의 (b)와 (e)는 변환되기 전 영상(original)이고, (a)와 (d)는 따 뜻한 쪽(warmer)으로 변환된 영상이며, (c)와 (f)는 시원한

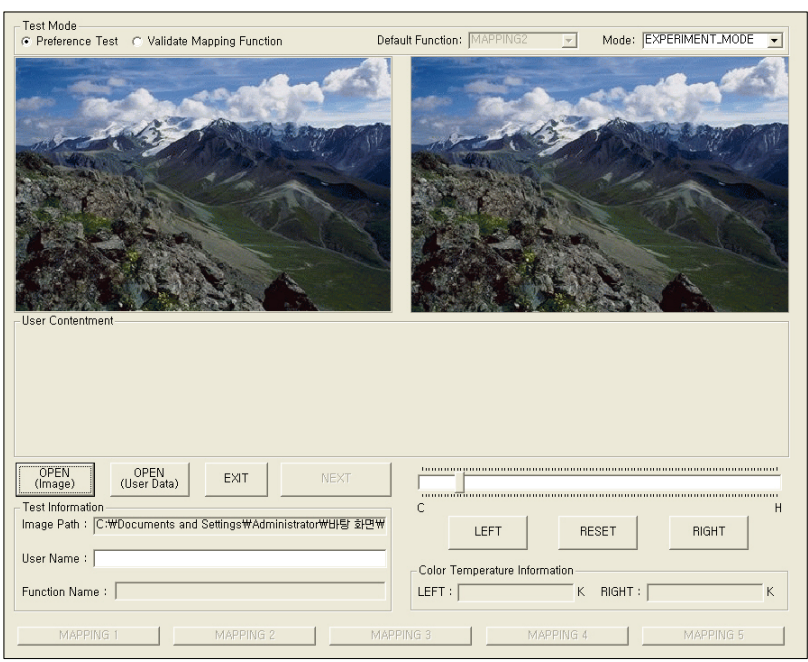

그림 5. 색온도 변환에 대한 사용자 선호 경향 조사를 위한 실험용 GUI Fig. 5. The experiment GUI of user preference tendency for color temperature conversion

쪽(cooler)으로 변환된 영상이다.

이와 같이 준비된 실험용 $\mathrm{GUI}$ 를 통해 색온도 변환에 대 한 사용자 선호 경향에 대한 조사 실험을 3회에 걸쳐 수행 하였다. 1 차 실험은 기존 연구 ${ }^{[9]}$ 에서 보고된, 색온도 변환에 대한 사용자 선호 경향을 검증하기 위한 실험이다. 2,3 차 실험은 이전 실험의 결과를 바탕으로, 한 번 이상 변환된 영상 색온도의 재 변환 가능성에 대한 조사와 검증을 위한 실험이다.

이를 위해 2차 실험부터는 이전 실험을 수행한 다음, 약 1 주일 후에 각 실험대상자 별로 이전 실험에서 본인이 원하 는 색온도로 변환했었던 영상을 보여주고, 다시 한 번 색온 도를 변환하도록 유도하였다. 이 때 실험대상자들에게는 이전 실험의 영상을 다시 보여주는지, 변환된 영상을 보여

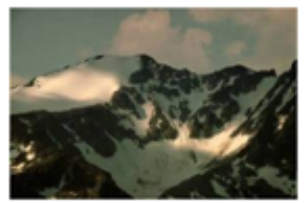

(a)

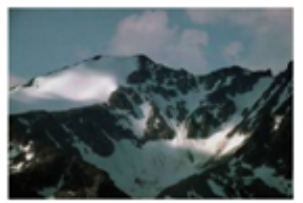

(b)

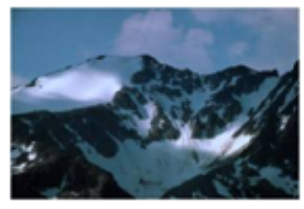

(c)

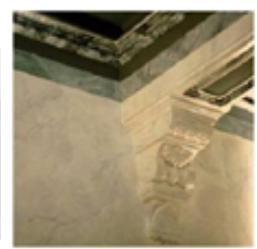

(d)

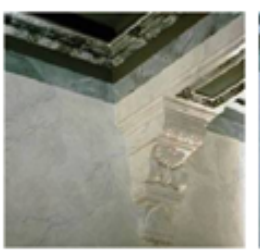

(e)

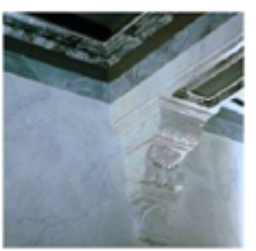

(f)

그림 6. 색온도가 변환된 영상의 예

Fig. 6. Image examples of converted color temperature 
주는지에 대해 알려주지 않았다. 모든 실험은 동일한 절차 와 제약 사항을 가지고 수행하였으며, 실험대상자들에게 다음과 같은 실험 절차와 제약 사항을 안내하고, 따르도록 지시하였다.

\section{1. 실험 절차}

(1) 실험대상자는 실험용 GUI에 본인의 이름을 적고, 왼 쪽의 영상보다 오른쪽의 영상이 실험대상자의 기호 에 따라 더 좋아 보일 때까지 슬라이드 바를 움직이 거나 LEFT, RIGHT 버튼을 눌러 오른쪽 영상의 색온 도를 변환시킨다.

(2) LEFT, RIGHT 버튼의 움직임에 따른 영상 색온도의 변환은, 왼쪽(LEFT)으로 이동할 경우 색온도가 증가 하면서 더 시원한 느낌(cooler)의 영상으로 변화되고, 오른쪽(RIGHT)으로 이동할 경우 색온도가 감소하면 서 더 따뜻한 느낌(warmer)의 영상으로 변화된다. 이 버튼들은 정밀한 색온도 변환에 사용된다. LEFT, RIGHT 버튼을 누를 때 역색온도 단위로 5 만큼씩 색 온도가 변화한다. RESET 버튼은 실험대상자가 원 영상의 조건을 선호할 때 누르면 오른쪽 영상이 원 영상의 색온도로 변환된다.

(3) 슬라이드 바의 움직임에 따른 영상 색온도의 변환은, 왼쪽으로 이동할 경우 색온도가 증가하면서 더 시원 한 느낌의 영상으로 변화되고, 오른쪽으로 이동할 경 우 색온도가 감소하면서 더 따뜻한 느낌의 영상으로 변화된다. 슬라이드 바는 버튼에 비해 좀 더 많은 변
화량을 줄 때 사용된다.

(4) 버튼과 슬라이드 바를 통해 색온도 변환이 끝나면, 더 이상 준비된 영상이 없을 때까지 NEXT 버튼을 눌러 다음 영상을 변화시킨다.

\section{2. 제약 사항}

실험대상자는 원 영상의 자연스러운 색감을 크게 벗어나 지 않는 범위 내에서 색온도를 변환시키도록 제한하였다. 예를 들어 원 영상이 석양(붉은 하늘)에 대한 영상이라면, 파란 하늘과 같은 영상으로 변화시키지 못하도록 지시하였 다. 만약, 이 같은 지시사항을 따르지 않고 원 영상에 비해 부자연스러운 변화를 준 실험 결과는 분석 단계에서 제외 하였다. 실험 결과 분석에서 제외시키는 기준은, MPEG-7 색온도 서술자에서 제시된 4 가지의 색온도 카테고리 ${ }^{[12-14]}$ 를 기준으로 2 단계 이상의 변화가 발생했을 때 제외하도록 하였다. 예를 들어, 원 영상이 Hot 카테고리의 영상이었는 데 실험대상자가 변환한 결과 영상이 Moderate카테고리나 $\mathrm{Cool}$ 카테고리의 영상이 되었다면, 해당 영상의 변환 결과 는 실험 결과 분석에서 제외하였다.

\section{3. 실험 결과}

3.1. 색온도 변환에 대한 사용자의 선호 경향 조사 결과

그림 7은 첫 번째 실험 결과인, 색온도 변환에 대한 사용 자의 선호 경향 조사 결과를 보여준다. 그림 7의 (a)는 따뜻 한 쪽(warmer)을 선호하는 경향에 대해 각 영상이 속하는

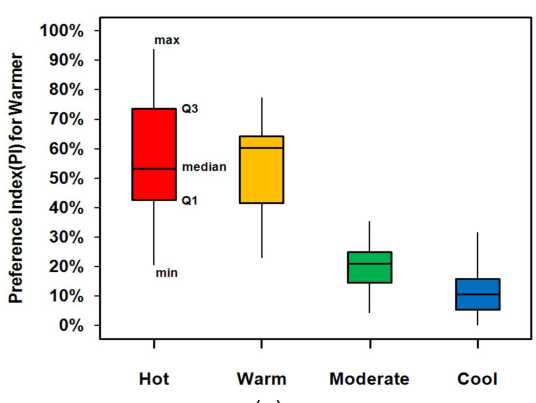

(a)

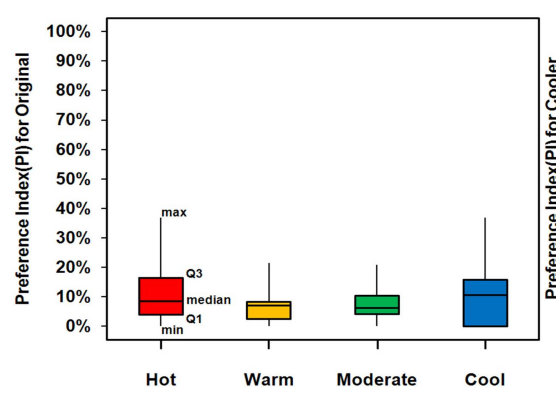

(b)

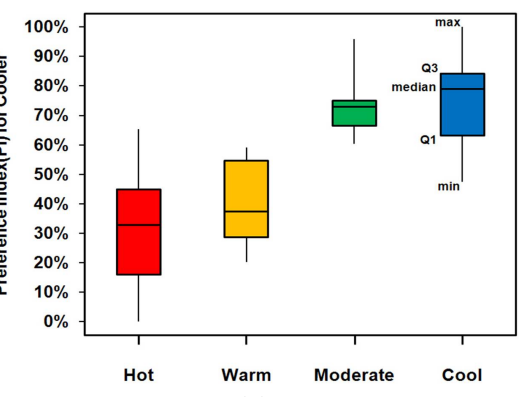

(c)

그림 7. 색온도 변환에 대한 사용자의 선호 경향 조사 결과

Fig. 7. The results of user preference tendency plots on the color temperature conversion 
색온도 카테고리 내의 사용자 선호도를 표시하였다. 그림 7의 (c)는 시원한 쪽(cooler)을 선호하는 경향을, (b)는 변하 지 않은 원 영상(original)을 선호하는 경향을 보여준다. 각 선호 경향 별 영상이 속하는 색온도 카테고리 내에서 사용 자의 선호도(preference index)를 표시하는 방법은 기존 연 구 $^{[9]}$ 에서 사용한 방법과 동일하다.

1 차 실험의 결과를 보면, 기존 연구 ${ }^{[9]}$ 에서의 사용자 선 호 경향 조사 결과와 비슷한 결과임을 알 수 있다. 즉, 색 온도 변환에 대한 사용자의 선호 경향은 원 영상을 그대 로 보는 것 보다, 따뜻한 느낌의 영상일수록(Hot, Warm) 더 따뜻하게 보고 싶어 하며, 시원한 느낌의 영상일수록 (Cool, Moderate) 더 시원하게 보고 싶어 하는 경향을 보 였다.

3.2. 색온도 재 변환에 대한 사용자의 선호 경향 조사 결과 그림 8은 두 번째와 세 번째 실험의 결과인, 색온도 재 변환에 대한 사용자의 선호 경향 조사 결과를 보여준다. 그 림 8의 (a) (c)는 두 번째 실험의 결과이며, (d) (f)는 세 번
째 실험의 결과이다. 그림 8 의 (a)와 (d)는 따뜻한 쪽 (warmer)을 선호하는 경향을, (c)와 (f)는 시원한 쪽(cooler) 을 선호하는 경향을, (b)와 (e)는 변하지 않은 원 영상 (original)을 선호하는 경향에 대해 각 영상이 속하는 색온 도 카테고리 내의 사용자 선호도를 표시하였다.

2,3 차 실험의 결과를 보면, 색온도 재 변환에 대한 실험 이 진행될수록, 변하지 않은 원 영상을 선호하는 경향 (original)에 대한 사용자의 선호도는 점차 증가하는 반면에 나머지 선호 경향들(warmer, cooler)에 대한 사용자의 선호 도는 점차 감소하는 것을 알 수 있다. 또한 여전히 따뜻한 느낌의 영상일수록(Hot, Warm) 더 따뜻하게, 시원한 느낌 의 영상일수록(Cool, Moderate) 더 시원하게 보고 싶어 하 는 경향도 존재하고 있음을 알 수 있다. 하지만, 점차 변하 지 않은 원 영상을 선호하는 경향이 다른 선호 경향들에 비해 두드러지기 때문에, 색온도 변환을 반복하는 것은 큰 의미가 없는 것으로 간주할 수 있다. 그러나 좀 더 객관적이 며 정량화된 평가 및 분석 결과를 도출하기 위하여, 일원분 산분석(ANOVA) 평가를 통해 색온도에 대한 사용자의 선

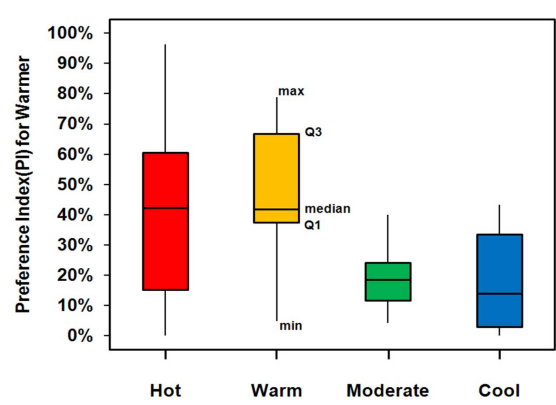

(a)

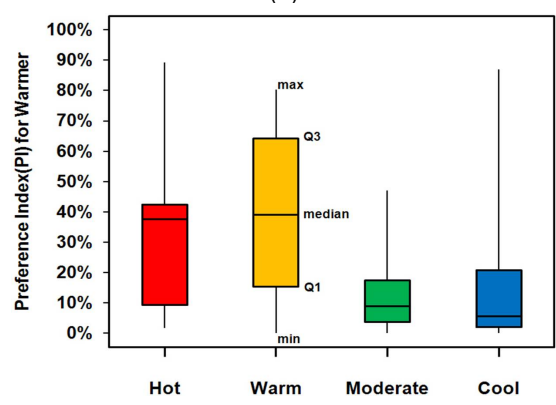

(d)

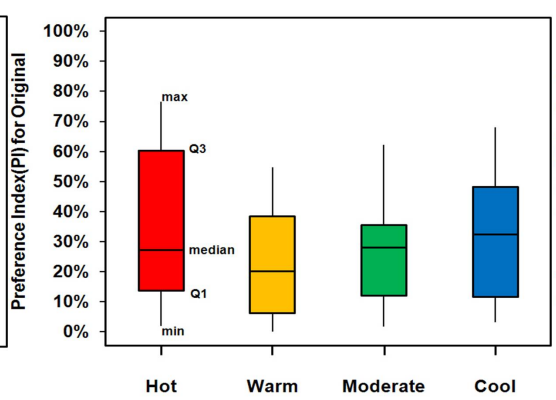

(b)

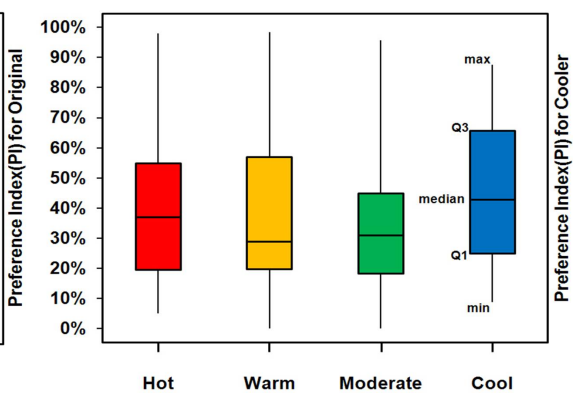

(e)

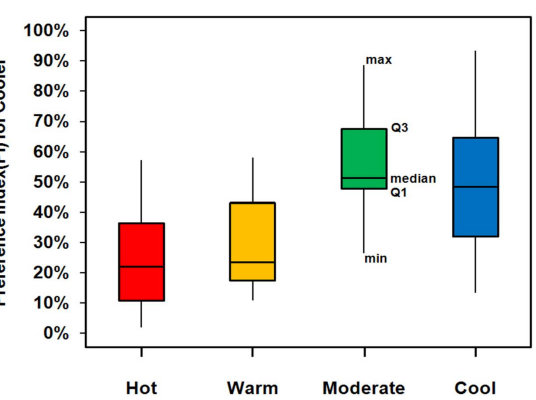

(c)

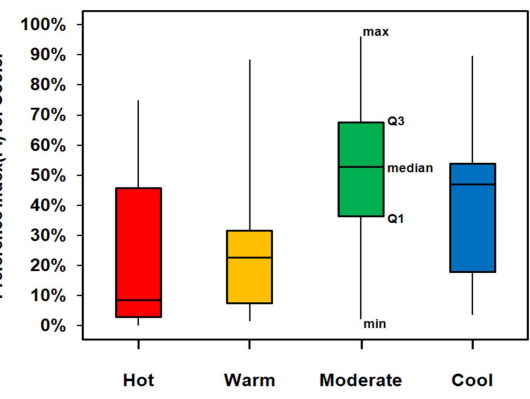

(f)

그림 8. 색온도 재 변환에 대한 사용자의 선호 경향 조사 결과

Fig. 8. The results of user preference tendency plots on the color temperature re-conversion 
호 경향을 분석하였다.

\section{IV. 색온도 변환에 대한 사용자의 선호 경향 분석}

\section{1. 색온도 변환에 대한 사용자의 선호 경향 분석}

일원분산분석(ANOVA, ANalysis Of VAriance)은 두 개 이상의 독립적 집단들의 평균치들을 비교할 수 있으며, 연 구 질문이 하나의 요인(factor)이나 독립변수만을 포함할 때 사용된다 ${ }^{[15]}$. 연구 질문인 '색온도 변환에 대한 사용자의 선호 경향에 대한 독립 집단들은, 각 색온도 카테고리 별로 따뜻한 쪽을 선호하는 경향(warmer)과, 시원한 쪽을 선호 하는 경향(cooler), 변하지 않은 원 영상을 선호하는 경향 (original)의 세 가지 경향으로 나눌 수 있다. 그리고 이 독 립집단들 간의 비교 대상인 독립변수(요인)들은, 각 경향을 선택한 횟수(백분율)들의 평균치들이 된다. 일원분산분석 을 수행하는 절차는 다음과 같다.

먼저, '영상의 색온도 변환에 대한 사용자 선호 경향'이 의미가 있는지에 대해 알아보기 위해서 $\mathrm{F}$ 검증을 수행한다.
$\mathrm{F}$ 검증은 $\mathrm{F}$ 요비(F ratio)가 $95 \%$ 신뢰구간에서의 $\mathrm{F}$ 임계치 $\left(\mathrm{F}_{005}\right)$ 보다 값이 큰지 확인하여 크다면 영가설 $\left(\mathrm{H}_{0}\right)$ 을 기각한 다. 여기서 $\mathrm{F}$ 검증을 수행할 때의 영가설 $\left(\mathrm{H}_{0}\right)$ 은 색온도 변 환에 대한 세 가지 사용자 선호 경향은 서로 차이가 없다' 이고, 대립가설 $\left(\mathrm{H}_{1}\right)$ 은'색온도 변환에 대한 세 가지 사용자 선호 경향은 서로 차이가 있다'이다. F 요비가 F 임계치 보 다 값이 크다는 것은 대립가설 $\left(\mathrm{H}_{1}\right)$ 이 사실이라는 것을 의미 하지만 어떤 선호 경향이 더 의미가 있는지 설명할 수는 없다.

따라서 어떤 선호 경향이 더 의미가 있는지 검증하기 위 해 Tukey's HSD(honestly significant difference) 검증을 통 해 이를 증명한다. Tukey's HSD 검증은 F 검증을 통해 대 립가설 $\left(\mathrm{H}_{1}\right)$ 이 사실로 판명되면 수행하고, 아니라면 수행할 필요가 없다. Tukey's HSD 검증은 색온도 선호 경향들 간 의 관계에 대한 차이(difference) 값들이 HSD 임계치(HSD critical value) 값보다 크다면, 해당하는 선호 경향들 간의 관계가 의미가 있다는 것을 증명하게 된다.

표 4 는 일원분산분석으로 1 차 실험의 결과를 분석한 결 과를 정리한 표이다. 표 4 에서 $\mathrm{F}$ 임계치 값은 3.19 로 모두 동일하며, 각 색온도 카테고리의 $\mathrm{F}$ 요비 값(Hot: 26.97, Warm: 53.22, Moderate: 312.80, Cool: 137.14)은 모두 F

표 4. 일원분산분석으로 색온도 변환에 대한 사용자의 선호 경향을 분석한 결과

Table 4. The analysis results of user preference tendency of converting color temperatures by the ANOVA

\begin{tabular}{|c|c|c|c|c|c|c|c|}
\hline & \multirow[b]{2}{*}{ Category } & \multicolumn{2}{|c|}{ ANOVA } & \multicolumn{4}{|c|}{ Tukey's HSD Verification ( $k=3, q=3.44)$} \\
\hline & & $\mathrm{F}$ ratio & $\begin{array}{c}\text { F.05(critical } \\
\text { value) }\end{array}$ & $\begin{array}{l}\text { Relationships } \\
\text { between } \\
\text { categories }\end{array}$ & Difference & HSD critical value & Significant \\
\hline \multirow{12}{*}{1} & \multirow{3}{*}{ Hot } & \multirow{3}{*}{26.97} & \multirow{12}{*}{3.19} & warmer $\sim$ original & 0.46 & \multirow{3}{*}{0.36} & Yes \\
\hline & & & & warmer $\sim$ cooler & 0.24 & & No \\
\hline & & & & cooler $\sim$ original & 0.22 & & No \\
\hline & \multirow{3}{*}{ Warm } & \multirow{3}{*}{53.22} & & warmer $\sim$ original & 0.46 & \multirow{3}{*}{0.26} & Yes \\
\hline & & & & warmer $\sim$ cooler & 0.14 & & No \\
\hline & & & & cooler $\sim$ original & 0.32 & & Yes \\
\hline & \multirow{3}{*}{ Moderate } & \multirow{3}{*}{312.80} & & cooler $\sim$ original & 0.65 & \multirow{3}{*}{0.16} & Yes \\
\hline & & & & cooler warmer & 0.53 & & Yes \\
\hline & & & & warmer $\sim$ original & 0.13 & & No \\
\hline & \multirow{3}{*}{ Cool } & \multirow{3}{*}{137.14} & & cooler original & 0.64 & \multirow{3}{*}{0.26} & Yes \\
\hline & & & & cooler warmer & 0.63 & & Yes \\
\hline & & & & warmer original & 0.01 & & No \\
\hline
\end{tabular}


임계치 값보다 크다. 따라서 각 색온도 카테고리 내에서 어 떤 경향이 더 의미가 있는지 알아보기 위해 모두 Tukey's $\mathrm{HSD}$ 검증을 수행하였다.

Tukey's HSD 검증에서는 각 경향들 간의 관계에 있어 먼저 서술된 경향이 더 의미가 있는 것으로 해석된다. 따라 서 Hot 카테고리에서는, 'warmer original' 관계에서 차이 값(0.46)이 HSD 임계치 값(0.36)보다 더 크므로, 따뜻한 쪽 (warmer)을 선호하는 경향이 원 영상(original)을 선호하는 경향보다 더 의미가 있다고 해석할 수 있다.

마찬가지 방법으로 해석하면, Warm 카테고리에서는 'warmer original' 관계와 'cooler original' 관계가 모두 의미가 있다. Warm 카테고리에서의 HSD 임계치 값은 0.26 이며, 'warmer original' 관계에서의 차이 값은 0.46 이고, 'cooler original' 관계에서의 차이 값은 0.32 로 $\mathrm{HSD}$ 임계치 값보다 크다. 그러나 'warmer original' 관계 가 'cooler original' 관계 보다 차이 값이 더 크므로 'warmer original' 관계가 더 의미가 있다. 따라서 Warm 카테고리에서는 원 영상(original)보다 시원한 쪽(cooler)으 로 변환하는 것을 선호하는 경향도 있지만, 따뜻한 쪽 (warmer)으로 변환하는 것을 더 선호한다고 해석할 수 있다.

Cool 카테고리와 Moderate 카테고리에서는 'cooler warmer' 관계(difference: Cool $=0.63$, Moderate $=0.53$ )와 'cooler $\sim$ original' 관계(difference: $\mathrm{Cool}=0.64$, Moderate $=$ 0.65)가 의미가 있다(difference > HSD critical value: Cool $=0.26$, Moderate $=0.16$ ). 따라서 Cool 카테고리와 Moderate 카테고리에서는 원 영상(original)보다 시원한 쪽(cooler)으 로 변환하는 것을 더 선호하며, 따뜻한 쪽(warmer)으로의 변화보다는 시원한 쪽(cooler)으로의 변화를 더 선호한다고 해석할 수 있다.

지금까지의 일원분산분석의 결과를 종합하면, 결국 색온 도 변환에 대한 사용자의 선호 경향은, 기존 연구 ${ }^{[9]}$ 에서의 조사 결과 같은 결론을 얻을 수 있다. 따라서 색온도 변환에 대한 사용자 선호 경향은 따뜻한 느낌의 영상일수록(Hot, Warm) 더 따뜻하게 보고 싶어 하며, 시원한 느낌의 영상일 수록(Cool, Moderate) 더 시원하게 보고 싶어 하는 경향을 보인다는 결론을 내릴 수 있다.

\section{2. 색온도 재 변환에 대한 사용자의 선호 경향 분석}

표 5 는 일원분산분석으로 2,3 차 실험의 결과를 분석한 결과를 정리한 표이며, $\mathrm{F}$ 임계치 값은 3.19로 모두 동일하 다. 2 차 실험에서는 Hot 카테고리를 제외한 나머지 색온도 카테고리의 F 요비 값(Hot: 2.13, Warm: 5.86, Moderate: 27.93, Cool: 10.91)은 F 임계치 값보다 크다. 또한, 3 차 실 험에서는 Moderate와 Cool 카테고리의 F 요비 값(Hot: 1.85, Warm: 1.51, Moderate: 12.90, Cool: 6.71)만이 F 임 계치 값보다 크다.

2차 실험에서의 Tukey's HSD 검증 결과를 보면, Moderate 카테고리의 'cooler warmer' 관계에서만 의미 가 있었다. Warm과 Cool 카테고리에서는 HSD 임계치 (Warm: 0.37, Cool: 0.41) 값보다 큰 차이 값을 가지는 선호 경향들 간의 관계가 없었다. Moderate 카테고리에서는 HSD 임계치(0.30) 보다 큰 값을 가지는 'cooler warmer' 관계의 차이 $(0.37)$ 에는 의미가 있지만 'cooler original' 관계의 차이(0.29)에는 의미가 없다. 즉, 원 영상의 색온도 변환에 대한 선호 경향은 따뜻한 쪽보다는 시원한 쪽으로 변하는 것이 더 의미가 있고, 시원한 쪽으로 변하는 것보다 는 변하지 않는 것이 더 의미가 있다고 해석된다. 따라서 2 차 실험의 결과, 대부분의 영상에 대한 2 차 색온도 변환의 결과는 큰 의미가 없다는 결론을 내릴 수 있다.

3차 실험에서의 Tukey's HSD 검증 결과는, 사용자가 Moderate와 Cool 카테고리 내에서 원 영상을 변환하지 않 는 것을 더 선호한다는 것을 알 수 있었다. 즉, Moderate와 Cool 카테고리에서는 HSD 임계치(Moderate: 0.44, Cool: 0.48 ) 값보다 큰 차이 값을 가지는, 색온도 선호 경향들 간 의 관계가 없었다. 결국, 2 차 실험에 대한 분석 결과와 마찬 가지로, 3 차 색온도 변환의 결과 또한 큰 의미가 없다는 결 론을 내릴 수 있다.

지금까지의 일원분산분석의 결과를 종합하면, 결국 색온 도 재 변환에 대한 사용자의 선호 경향은, 통계적으로 무의 미하다는 결론을 내릴 수 있다. 따라서 사용자의 색온도 선 호 경향을 반영한 영상의 색온도 변환은 한 번만 수행하는 것과 여러 번 수행하는 것과 차이가 없으므로, 한 번만 수행 하는 것이 더 효율적이다. 
표 5. 일원분산분석으로 색온도 재 변환에 대한 사용자의 선호 경향을 분석한 결과

Table 5. The analysis results of user preference tendency of re-converting color temperatures by the ANOVA

\begin{tabular}{|c|c|c|c|c|c|c|c|}
\hline & \multirow{2}{*}{ Category } & \multicolumn{2}{|c|}{ ANOVA } & \multicolumn{4}{|c|}{ Tukey's HSD Verification ( $k=3, q=3.44)$} \\
\hline & & F ratio & $\begin{array}{l}\text { F.05(critical } \\
\text { value) }\end{array}$ & $\begin{array}{l}\text { Relationships } \\
\text { between categories }\end{array}$ & Difference & HSD critical value & Significant \\
\hline \multirow{12}{*}{2} & & & \multirow{12}{*}{3.19} & - & - & & - \\
\hline & Hot & 2.13 & & - & - & - & - \\
\hline & & & & - & - & & - \\
\hline & \multirow{3}{*}{ Warm } & \multirow{3}{*}{5.86} & & warmer $\sim$ original & 0.21 & \multirow{3}{*}{0.37} & No \\
\hline & & & & warmer $\sim$ cooler & 0.14 & & No \\
\hline & & & & cooler $\sim$ original & 0.07 & & No \\
\hline & \multirow{3}{*}{ Moderate } & \multirow{3}{*}{27.93} & & cooler $\sim$ warmer & 0.37 & \multirow{3}{*}{0.30} & Yes \\
\hline & & & & cooler $\sim$ original & 0.29 & & No \\
\hline & & & & original $\sim$ warmer & 0.08 & & No \\
\hline & \multirow{3}{*}{ Cool } & \multirow{3}{*}{10.91} & & cooler $\sim$ warmer & 0.33 & \multirow{3}{*}{0.41} & No \\
\hline & & & & cooler $\sim$ original & 0.18 & & No \\
\hline & & & & original $\sim$ warmer & 0.15 & & No \\
\hline \multirow{12}{*}{3} & & & \multirow{12}{*}{3.19} & - & - & \multirow{3}{*}{-} & - \\
\hline & Hot & 1.85 & & - & - & & - \\
\hline & & & & - & - & & - \\
\hline & \multirow{3}{*}{ Warm } & \multirow{3}{*}{1.51} & & - & - & \multirow{3}{*}{ - } & - \\
\hline & & & & - & - & & - \\
\hline & & & & - & - & & - \\
\hline & \multirow{3}{*}{ Moderate } & \multirow{3}{*}{12.90} & & cooler $\sim$ warmer & 0.39 & \multirow{3}{*}{0.44} & No \\
\hline & & & & cooler $\sim$ original & 0.18 & & No \\
\hline & & & & original $\sim$ warmer & 0.21 & & No \\
\hline & \multirow{3}{*}{ Cool } & \multirow{3}{*}{6.71} & & original $\sim$ warmer & 0.28 & \multirow{3}{*}{0.48} & No \\
\hline & & & & original $\sim$ cooler & 0.03 & & No \\
\hline & & & & cooler warmer & 0.25 & & No \\
\hline
\end{tabular}

\section{3. 최적의 색온도 변환 곡선}

그림 9는 여러 번에 걸친, 각각의 색온도 변환에 대한 사 용자 선호 조사 실험에서의 색온도 변화량에 대한 데이터 를 정리하여 보여주는 그림이다. 그림 9의 (a)는 1차, (b)는 2 차, (c)는 3 차 실험에 대한 데이터를 정리한 결과를 보여주 는 분포도로서, 그림의 곡선 중 실선은 곡선 접합(curve fitting) 방법에 의해 유도된 4차 방정식의 곡선이며, 점선은 유도된 방정식의 오차 범위 $(50 \%$ 이내)를 표시하는 곡선이 다. 그림 9에서는 실험이 반복될수록 색온도 변화량이 줄어
드는 것을 볼 수 있는데, 앞서 일원분산분석을 통해 분석한 결과와 일치하는 결과이다.

이와 같이 색온도 변화량에 대한 데이터와 색온도 변환 에 대한 사용자 선호 경향이 일치하므로, 1 차 실험에서의 색온도 변화량을 바탕으로 그림 10에서와 같은 색온도 변 환 곡선을 유도하였다. 그림 10 에서의 색온도 변환 곡선은 그림 9 (a)에서 유도된 4차방정식을 바탕으로 곡선의 시작 과 끝이 0으로 맵핑될 수 있도록 조정한 뒤, 다시 유도된 4 차 방정식의 곡선이다. 이 곡선은 결국, 대부분의 사용자 들의 색온도 변환에 대한 선호 경향인, 따뜻한 느낌의 영상 


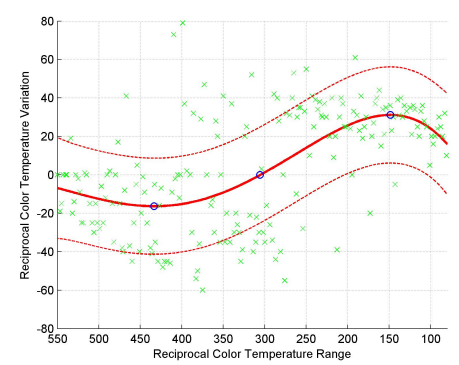

(a)

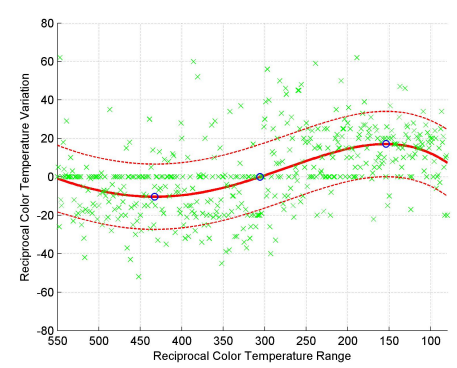

(b)

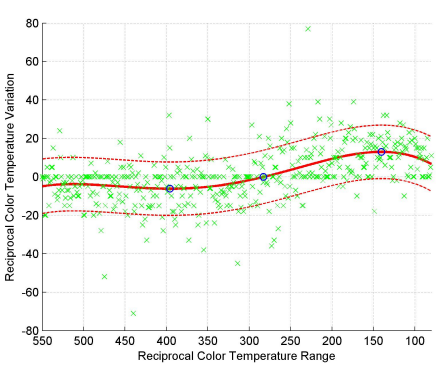

(c)

그림 9. 각 회 차별 실험에서의 색온도 변화량

Fig. 9. Variations of the user-preferred color temperatures

(Hot, Warm)은 더 따뜻하게(warmer, 색온도 낮음), 시원한 느낌의 영상(Cool, Moderate)은 더 시원하게(cooler, 색온 도 높음) 볼 수 있도록 색온도를 변환하는 것을 반영한 것 이다. 따라서 차후 이 색온도 변환 곡선의 형태를 적용한 최적의 색온도 변환 방법이 연구될 필요가 있다.

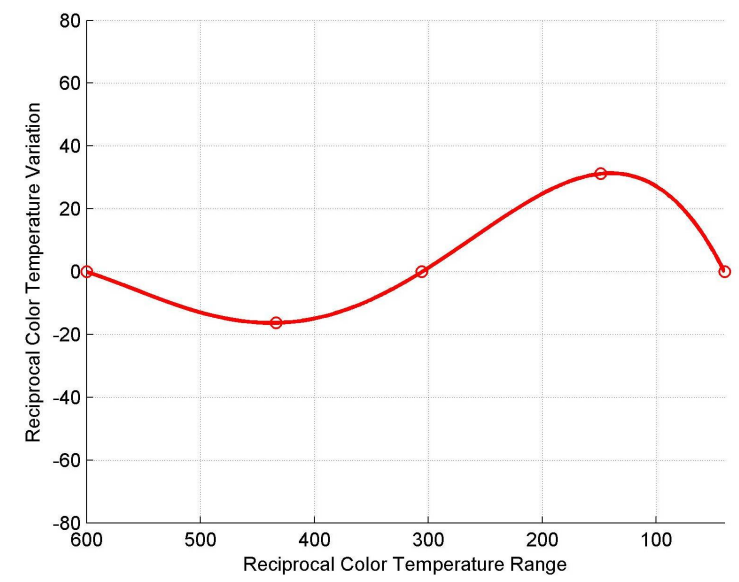

그림 10. 사용자 선호 경향 따라 유도된 색온도 변환 곡선

Fig. 10. The derived color temperature conversion curve derived from user preference tendency test

\section{V. 결 론}

본 논문에서는 영상 색온도 변환에 대한 사용자 선호 경 향에 대한 분석을 실시하여, 최적의 색온도 변환을 위한 색 온도 변환 곡선을 제시하였다. 이를 위해, 기존 연구 ${ }^{[9]}$ 에서
제안된 색온도 방법에 대한 성능 평가 실험을 통해 개선되 어야 할 점을 제시하였다. 또한, 기존 연구 결과의 바탕이 되는 영상 색온도 변환에 대한 사용자의 선호 경향을 검증 하고, 한 번 이상 변환된 영상 색온도의 재 변환 가능성에 대한 조사와 검증을 위해, 색온도 변환에 대한 사용자 선호 경향 조사 실험을 3회에 걸쳐 반복 수행하였다.

실험 결과에 대한 객관적이고 정량적인 분석을 위해 일 원분산분석(ANOVA) 평가를 실시하였다. 그 결과, 기존 연 구 $^{[9]}$ 에서와 같이 색온도 변환에 대한 사용자의 선호 경향 은, 따뜻한 느낌의 영상일수록 더 따뜻하게, 시원한 느낌의 영상일수록 더 시원하게 보고 싶어 하는 것으로 분석되었 다. 또한, 색온도 재 변환에 대한 사용자 선호 경향에 대한 분석 결과, 한 번 이상 색온도를 변환하는 것은 통계적으로 무의미한 것으로 분석되었다.

결국, 색온도 변환에 대한 사용자의 선호 경향을 고려하 여 색온도 변환을 수행하는 것은 한 번만 수행하는 것이 더 효율적임이 증명되었다. 이와 같은 결과를 바탕으로 1차 실험에서의 색온도 변화량에 데이터를 이용하여 색온도 변 환 곡선을 유도하였다. 이렇게 유도된 색온도 변환 곡선은 결국, 색온도 변환에 대한 사용자의 선호 경향을 반영한 최 적의 색온도 변환 곡선이라고 할 수 있다.

따라서 차후에는, 본 논문에서 제시된 색온도 변환 곡선 을 바탕으로, 색온도 변환에 대한 사용자 선호 경향을 반영 한 최적의 색온도 변환 방법이 연구되어야 할 필요가 있다. 또한, 사용자의 선호 경향이 꼭 분석 결과에 대응되지 않을 수도 있으므로, 사용자 맞춤형 색온도 변환 방법 또한 함께 
고려되어야 할 필요가 있다.

\section{참 고 문 헌}

[1] 권오설, 고경우, 하영호, "평균화면밝기에 기반한 PDP 디스플레이의 특성화 및 색 재현", 전자공학회논문지, 제 45 권, 제 5 호, pp.9-17, 2008 년 9월.

[2] 장수욱, 표세진, 김은수, 이성학, 송규익, "APL 적용 오차 확산법을 이 용한 PDP 화질 개선”, 멀티미디어학회논문지, 제 8 권, 제 10 호, pp. 1360-1368, 2005년 10월.

[3] Ki-Duck Cho, Heung-Sik Tae, Sung-Il Chien, "Improvement of Color Temperature Using Independent Control of Red, Green, Blue Luminance in AC Plasma Display Panel", IEEE transactions on electron devices, Vol. 50, NO. 2, pp.359-365, Feb. 2003.

[4] 김광현, 한영준, 한헌수, “블록기반 지역 명암대비 개선을 통한 전역 명 암대비 향상 기법”, 전자공학회논문지, 제 45 권, 제 1 호, pp. 15 - 24,2008 년 1월.

[5] 이금분, 조범준, "영상 향상을 위한 자동 임계점 선택 및 대비 강화 기 법”, 멀티미디어학회논문지, 제 11 권, 제4호, pp.462-470, 2008년 4월.

[6] 이지원, 박래홍, "변형된 오차확산을 이용한 컬러 영상의 콘트라스트 개선”, 방송공학회논문지, 제13권, 제5호, pp.651-661, 2008년 9월.
[7] 김대희, 홍상기, 정재영, 조맹섭, "PDP에서의 관측자 선호 자연색에 관한 연구”, 학국색채학회 논문집, 제 16 권, 제 2,3 호, pp.69-75, 2002년 12월.

[8] 정재영, 김대희, 홍상기, 조맹섭, “관측자의 심리물리학적 실험을 통한 히스토그램 알고리즘 적용 영상 선호도 분석”, 한국색채학회 논문집, 제16권, 제1호, pp.19-25, 2002년 6월.

[9] Sang-Kyun Kim, Du-Sik Park, Won-Hee Choi, Seong-Deok Lee, "Color Temperature Conversion for Video on TV or PC Reflecting Human's Display Preference Tendency”, ICCIT 2007, pp.861-867, Nov. 2007.

[10] Gunter Wyszecki and W.S. Stiles, Color Science, Concepts and Methods, Quantitative Data and Formulae, 2nd Edition, John Wiley \& Sons, New York, pp.224-225, 1982.

[11] 모유석, 유기주, 이재기, 정운달, "색온도 보정을 이용한 영상 개선", 한국화상학회지, 제3권, 제1호, pp.98-107, 1997년 1월.

[12] ISO/IEC JTC1/SC29/WG11 M7265, "Report of VCE-6 on MPEG-7 Color Temperature Browsing Descriptors", Sydney, Jul. 2001.

[13] ISO/IEC JTC1/SC29/WG11 M7712, "Report of VCE-6 on MPEG-7 Color Temperature Browsing Descriptors", Pattaya, Dec. 2001.

[14] ISO/IEC JTC1/SC29/WG11 M7993, "Report of VCE-6 on MPEG-7 Color Temperature Descriptor for Display Preference", Jeju, Mar. 2002.

[15] 김아영, 차정은, 통계분석 논리의 기초, 제2판, 박학사, 서울, pp.343 368, 2006년.

\section{저 자 소 개}

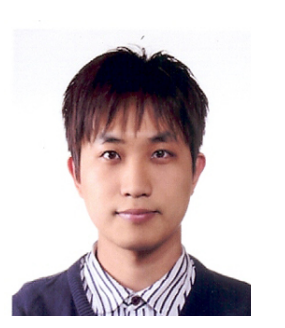

\section{주 용 수}

- 2008년 : 명지대학교 컴퓨터공학과 (학사)

- 2010년 : 명지대학교 컴퓨터공학과 (석사)

- 2010년 현재 : 명지대학교 컴퓨터공학과 박사과정

- 주관심분야 : 이미지비디오 처리 및 분석, 실감미디어 처리, MPEG-V

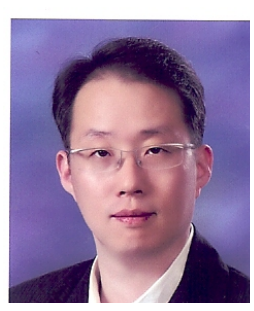

\section{김 상 균}

- 1991년 : Univ. of lowa, Computer Science (학사)

- 1994년 : Univ. of lowa, Computer Science (석사)

- 1997년 : Univ. of lowa, Computer Science (박사)

- 1997년 2007년 : 삼성종합기술원 멀티미디어랩 수석연구원

- 2007년 현재 : 명지대학교 컴퓨터공학과 조교수

- 주관심분야 : 이미지/비디오 처리 및 분석, 이미지 검색 및 인덱싱, 실감미디어 처리, MPEG-7, MPEG-V, multi-modal analysis 